\title{
Insertion of heterometals into the NifEN-associated iron-molybdenum cofactor precursor
}

\author{
Janice M. Yoshizawa $\cdot$ Aaron W. Fay $\cdot$ \\ Chi Chung Lee $\cdot$ Yilin $\mathrm{Hu} \cdot$ Markus Walter Ribbe
}

Received: 1 October 2009/Accepted: 20 November 2009/Published online: 5 December 2009

(c) The Author(s) 2009. This article is published with open access at Springerlink.com

\begin{abstract}
The cofactors of Mo-, V-, Fe-dependent nitrogenases are believed to be highly homologous in structure despite the different types of heterometals (Mo, V, and $\mathrm{Fe}$ ) they contain. Previously, a precursor form of the FeMo cofactor (FeMoco) was captured on NifEN, a scaffold protein for FeMoco biosynthesis. This all-Fe precursor closely resembles the $\mathrm{Fe} / \mathrm{S}$ core structure of the FeMoco and, therefore, could reasonably serve as a precursor for all nitrogenase cofactors. Here, we report the heterologous incorporation of $\mathrm{V}$ and $\mathrm{Fe}$ into the NifEN-associated FeMoco precursor. EPR and activity analyses indicate that $\mathrm{V}$ and $\mathrm{Fe}$ can be inserted at much reduced efficiencies compared with $\mathrm{Mo}$, and incorporation of both $\mathrm{V}$ and $\mathrm{Fe}$ is enhanced in the presence of homocitrate. Further, native polyacrylamide gel electrophoresis experiments suggest that NifEN undergoes a significant conformational rearrangement upon metal insertion, which allows the subsequent NifEN-MoFe protein interactions and the transfer of the cofactor between the two proteins. The combined outcome of these in vitro studies leads to the proposal of a selective mechanism that is utilized in vivo to maintain the specificity of heterometals in nitrogenase cofactors, which is likely accomplished through the redox regulation of metal mobilization by different $\mathrm{Fe}$ proteins (encoded by nifH,
\end{abstract}

J. M. Yoshizawa · A. W. Fay · C. C. Lee · Y. Hu (囚) .

M. W. Ribbe $(\square)$

Department of Molecular Biology and Biochemistry,

University of California,

2448 McGaugh Hall,

Irvine, CA 92697-3900, USA

e-mail: yilinh@uci.edu

M. W. Ribbe

e-mail: mribbe@uci.edu $v n f H$, and $a n f H$, respectively), as well as the differential interactions between these $\mathrm{Fe}$ proteins and their respective scaffold proteins (NifEN and VnfEN) in the Mo-, V-, and Fe-dependent nitrogenase systems.

Keywords Nitrogenase $\cdot$ Heterometal $\cdot$ NifEN · Iron-molybdenum cofactor - Assembly

\section{Introduction}

Nitrogenase is a complex metalloprotein that provides the biochemical machinery for the nucleotide-dependent reduction of dinitrogen $\left(\mathrm{N}_{2}\right)$ to ammonia $\left(\mathrm{NH}_{3}\right)$. Three homologous nitrogenases, which are distinguished by the heterometals (i.e., $\mathrm{Mo}, \mathrm{V}$, and $\mathrm{Fe}$ ) at their respective cofactor centers, have been identified to date [1]. Among them, the most extensively studied member is the Mo-dependent nitrogenase, which consists of two redoxactive proteins: the $\mathrm{Fe}$ protein and the $\mathrm{MoFe}$ protein. The $\mathrm{Fe}$ protein (encoded by nifH) is an $\alpha_{2}$-dimer of approximately $60 \mathrm{kDa}$, which has a $\left[\mathrm{Fe}_{4} \mathrm{~S}_{4}\right]$ cluster bound between the subunits and a nucleotide (i.e., MgATP) binding site located within each subunit; whereas the MoFe protein (encoded by nifD and nifK) is an $\alpha_{2} \beta_{2}$-tetramer of approximately $230 \mathrm{kDa}$, which has a P-cluster $\left(\left[\mathrm{Fe}_{8} \mathrm{~S}_{7}\right]\right)$ bridged between each $\alpha / \beta$ subunit dimer and an FeMoco ([ $\mathrm{MoFe}_{7} \mathrm{~S}_{9} \mathrm{X}$-homocitrate], where $\mathrm{X}$ is $\mathrm{C}, \mathrm{N}$, or $\mathrm{O}$ ) buried within each $\alpha$-subunit [2]. Catalysis by this nitrogenase involves repeated association and dissociation between the Fe protein and the MoFe protein and the ATP-dependent electron transfer within the $\mathrm{Fe}$ protein/MoFe protein complex from the $\left[\mathrm{Fe}_{4} \mathrm{~S}_{4}\right]$ cluster of the $\mathrm{Fe}$ protein, through the P-cluster, to the FeMoco of the MoFe protein, where substrate is reduced [3]. 
The V- and Fe-dependent nitrogenases are also twocomponent systems comprising $\mathrm{Fe}$ protein (encoded by $v n f H) / \mathrm{VFe}$ protein (encoded by $v n f D, v n f G$, and $v n f K$ ), and $\mathrm{Fe}$ protein (encoded by anfH)/FeFe protein (encoded by anfD, anfG, and anfK), respectively [1]. The Fe proteins of $\mathrm{V}$ - and Fe-dependent nitrogenases share a significant degree of sequence homology with their counterpart in the Mo-dependent nitrogenase, all of which are $\alpha_{2}$-dimers containing a single $\left[\mathrm{Fe}_{4} \mathrm{~S}_{4}\right]$ cluster [1]. Except for the presence of an additional small subunit (encoded by vnfG and $\operatorname{anf} G$, respectively), the $\mathrm{VFe}$ and $\mathrm{FeFe}$ proteins are also homologous to the MoFe protein, both in the primary sequence and in the types of metal centers they contain (i.e., both have the P-cluster and the cofactor centers that are homologous to those found in the Mo-dependent nitrogenase). In particular, the cofactor centers of $\mathrm{VFe}$ protein (i.e., $\mathrm{FeVco}$ ) and $\mathrm{FeFe}$ protein (i.e., FeFeco) are believed to be structurally homologous to FeMoco and, at least in the case of $\mathrm{FeVco}$, it has been reported that its $\mathrm{Fe} / \mathrm{S}$ core structure is very similar to that of the FeMoco [4]. The catalytic mechanisms of the V- and Fe-dependent nitrogenases likely resemble that of the Mo-dependent system, which requires the participation of both component proteins and the sequential electron transfer toward their respective cofactor sites. On the other hand, the substratereducing profiles of $\mathrm{V}$ - and $\mathrm{Fe}$ - dependent nitrogenases are similar to yet distinct from that of their Mo counterpart, and the different heterometal constituents in their cofactor centers likely contribute to their altered catalytic capacities.

All three nitrogenase cofactors (i.e., FeMoco, FeVco, and FeFeco) share the same apparatus at the early stages of biosynthesis. Assembly of all cofactors is presumably initiated by NifU and NifS (encoded by nifU and nifS), which mobilize $\mathrm{Fe}$ and $\mathrm{S}$ for the biosynthesis of small $\mathrm{Fe} / \mathrm{S}$ fragments. These small $\mathrm{Fe} / \mathrm{S}$ clusters are then transferred to NifB (encoded by $n i f B$ ) and further processed into a large $\mathrm{Fe} / \mathrm{S}$ core that possibly contains all $\mathrm{Fe}$ and $\mathrm{S}$ necessary for the generation of a mature cofactor. The biosynthetic pathway of nitrogenase cofactor is believed to branch at this point, which leads to the formation of FeMoco if the Fe/S core is further matured on NifEN (encoded by nifE and nif $N$ ), or the formation of $\mathrm{FeVco}$ and $\mathrm{FeFeco}$ if the Fe/S core is further matured on VnfEN (encoded by vnfE and vnfN) [5].

The role of NifEN as a scaffold protein for FeMoco maturation was initially proposed on the basis of a significant degree of sequence homology between NifEN and MoFe protein, which has led to the hypothesis that NifEN contains a "P-cluster site" that houses a P-cluster homolog and an "FeMoco site" that hosts the conversion of FeMoco precursor to a mature cofactor [5]. Recently, a Mo/homocitrate-free precursor, which closely resembles the $\mathrm{Fe} / \mathrm{S}$ core of the mature FeMoco, was captured on NifEN of Azotobacter vinelandii [6, 7]. In an ATP-dependent process, this NifEN-associated precursor can be converted to a mature FeMoco upon insertion of Mo and homocitrate by Fe protein. Following the maturation of the precursor, NifEN can serve as an FeMoco source and directly activate the FeMoco-deficient $\Delta$ nifB $\mathrm{MoFe}$ protein $[8,9]$. Identification of such an all-Fe precursor implies that, instead of being assembled by the previously postulated mechanism that involves the coupling of $\left[\mathrm{Fe}_{4} \mathrm{~S}_{3}\right]$ and $\left[\mathrm{MoFe}_{3} \mathrm{~S}_{3}\right]$ subclusters, the FeMoco is assembled by having the complete $\mathrm{Fe} / \mathrm{S}$ core structure in place before the insertion of Mo. Moreover, given the homology among the three nitrogenase cofactors, such an $\mathrm{Fe} / \mathrm{S}$ core could reasonably act as a precursor for all cofactors. Transformation to FeVco could occur by insertion of $\mathrm{V}$ (instead of Mo) along with homocitrate into the precursor, whereas conversion to FeFeco could take place by insertion of Fe (instead of Mo) along with homocitrate into the precursor or by having the precursor proceed as is for homocitrate attachment.

Here, we report the heterologous incorporation of $\mathrm{V}$ and Fe into the NifEN-associated FeMoco precursor. EPR and activity analyses indicate that $\mathrm{V}$ and $\mathrm{Fe}$ can be inserted at much reduced efficiencies compared with Mo, and incorporation of both $\mathrm{V}$ and $\mathrm{Fe}$ is enhanced in the presence of homocitrate. Further, native polyacrylamide gel electrophoresis (PAGE) experiments suggest that NifEN undergoes a significant conformational rearrangement upon metal insertion, which allows the subsequent NifEN-MoFe protein interactions and the transfer of the cofactor between the two proteins. The combined outcome of these in vitro studies leads to the proposal of a selective mechanism that is utilized in vivo to maintain the specificity of heterometals in nitrogenase cofactors, which is likely accomplished through the redox regulation of metal mobilization by different Fe proteins (encoded by nifH, vnfH, and anfH, respectively), as well as the differential interactions between these $\mathrm{Fe}$ proteins and their respective scaffold proteins (NifEN and VnfEN).

\section{Materials and methods}

Unless noted otherwise, all chemicals and reagents were obtained from Fisher Scientific or Sigma-Aldrich.

Cell growth and protein purification

All A. vinelandii strains were grown in $180-\mathrm{L}$ batches in a 200-L New Brunswick fermentor (New Brunswick Scientific, Edison, NJ, USA) in Burke's minimal medium supplemented with $2 \mathrm{mM}$ ammonium acetate. The growth rate was measured by the cell density at $436 \mathrm{~nm}$ using a Spectronic 20 Genesys (Spectronic Instruments, Westbury, NY, USA). After ammonium consumption, the cells were 
derepressed for $3 \mathrm{~h}$, followed by harvesting using a flowthrough centrifugal harvestor (Cepa, Lahr, Germany). The cell paste was washed with $50 \mathrm{mM}$ tris(hydroxymethyl)aminomethane (Tris)-HCl (pH 8.0). Published methods were used for the purification of His-tagged NifEN, His-tagged $\triangle$ nifB MoFe protein, and nontagged $\mathrm{Fe}$ protein from A. vinelandii strains DJ1041, DJ1143, and AvOP, respectively [6, 10-12].

\section{Maturation assays}

The conversion of NifEN-associated precursor to "FeMoco", "FeVco", or "FeFeco" was performed in a $50-\mathrm{mL}$ maturation assay containing $25 \mathrm{mM}$ Tris- $\mathrm{HCl}(\mathrm{pH}$ 8.0), $100 \mathrm{mg}$ precursor-bound NifEN (designated NifEN $^{\text {Precursor }}$ ), $120 \mathrm{mg}$ Fe protein, $0.4 \mathrm{mM}$ homocitrate, $2.4 \mathrm{mM}$ ATP, $4.8 \mathrm{mM} \mathrm{MgCl}, 30 \mathrm{mM}$ creatine phosphate, 24 units $/ \mathrm{mL}$ creatine phosphokinase, $20 \mathrm{mM}$ dithionite $\left(\mathrm{Na}_{2} \mathrm{~S}_{2} \mathrm{O}_{4}\right)$, and $0.4 \mathrm{mM} \mathrm{Na} 2 \mathrm{MoO}_{4}, \mathrm{NH}_{4} \mathrm{VO}_{3}$, or $\mathrm{FeCl}_{3}$, respectively. The conversion of NifEN-associated precursor to the homocitrate-free "FeMo", "FeV", or "FeFe" cluster was performed using the same procedure as described above, except that homocitrate was omitted from the maturation assay. In all cases, the maturation mixtures were stirred for $1 \mathrm{~h}$ at $30{ }^{\circ} \mathrm{C}$ and, subsequently, the various NifEN forms were reisolated (designated NifEN "FeMoco", NifEN" “FeVco", NifEN"FeFeco", NifEN"FeMo", NifEN “FeV”, and NifEN "FeFe", respectively) and subjected to EPR, reconstitution, and electrophoresis experiments.

\section{EPR spectroscopy}

All EPR spectroscopy samples were prepared in a Vacuum Atmospheres dry box (Vacuum Atmospheres, Hawthorne, CA, USA) at an oxygen level of less than $4 \mathrm{ppm}$. The dithionite-reduced samples contained $15 \mathrm{mg} / \mathrm{mL}$ protein, $10 \%$ glycerol, $2 \mathrm{mM} \mathrm{Na} \mathrm{S}_{2} \mathrm{O}_{4}$, and $25 \mathrm{mM}$ Tris- $\mathrm{HCl}(\mathrm{pH}$ 8.0). The indigo disulfonate (IDS)-oxidized samples were prepared by incubating proteins with excess IDS for $30 \mathrm{~min}$ and subsequently removing IDS using an anionexchange column. Spectra were collected in perpendicular mode using a Bruker ESP $300 \quad \mathrm{E}_{\mathrm{z}}$ spectrophotometer (Bruker, Billerica, MA, USA) interfaced with an Oxford Instruments ESR-9002 liquid-helium continuous-flow cryostat (Oxford Instruments, Oxford, UK). All spectra were recorded using a gain of $5 \times 10^{4}$, a modulation frequency of $100 \mathrm{kHz}$, a modulation amplitude of $5 \mathrm{G}$, and a microwave frequency of $9.62 \mathrm{GHz}$.

\section{Reconstitution analysis}

The reconstitution of the FeMoco-deficient $\Delta$ nifB MoFe protein was performed in a $0.8-\mathrm{mL}$ assay containing
$25 \mathrm{mM}$ Tris- $\mathrm{HCl}$ (pH 8.0), $20 \mathrm{mM} \mathrm{Na} \mathrm{S}_{2} \mathrm{O}_{4}$, and $0.5 \mathrm{mg}$ $\triangle$ nifB MoFe protein. Insertion of various cofactors/clusters was initiated by the addition of $2 \mathrm{mg}$ cofactor/clusterbound NifEN (see "Maturation assays") to the assay, and the reaction mixture was then incubated for $30 \mathrm{~min}$ at $30{ }^{\circ} \mathrm{C}$ before being terminated and examined for enzymatic activities as described earlier [13].

\section{Anaerobic native PAGE}

Native PAGE of equimolar mixtures of $\triangle$ nifB MoFe protein $(230 \mathrm{kDa})$ and various NifEN forms $(210 \mathrm{kDa})$ containing different cofactor/cluster sources was performed in a Vacuum Atmospheres dry box at an oxygen level of less than $4 \mathrm{ppm}$. A precast $7.5 \%$ Tris- $\mathrm{HCl}$ gel (Bio-Rad) was prerun at $80 \mathrm{~V}$ for $1 \mathrm{~h}$ in an anaerobic running buffer containing $2 \mathrm{mM}$ dithionite before the protein samples were loaded in the sample wells of the gel. Each sample contained $25 \mathrm{mM}$ Tris- $\mathrm{HCl}(\mathrm{pH} 8.0), 80 \%$ glycerol, $7 \mu \mathrm{g} \Delta$ nifB $\mathrm{MoFe}$ protein and $8 \mu \mathrm{g}$ of one of the various NifEN forms (i.e., NifEN $^{\text {Precursor }}$, NifEN “FeMoco", NifEN “FeMo", NifEN"FeVco", NifEN "FeV", NifEN "FeFeco", and NifEN"FeFe") so that the molar ratio between $\triangle$ nifB MoFe protein and NifEN was approximately $1: 1$ in all cases. The gel was stained by Coomassie blue upon the completion of electrophoresis.

\section{Results}

Previously, an "FeMoco"-bound form of NifEN was generated by incubating NifEN ${ }^{\text {Precursor }}$ with $\mathrm{Fe}$ protein, $\mathrm{MgATP}$, dithionite, $\mathrm{MoO}_{4}{ }^{2-}$, and homocitrate and reisolating NifEN (i.e., NifEN "FeMoco") after such a treatment [14]. Recently, a "FeMo"-cluster-bound form of NifEN (i.e., NifEN"FeMo") was obtained by the same procedure, except that homocitrate was omitted from the incubation mixture (unpublished data). Such an "FeMo" cluster is a homocitrate-free yet Mo-containing equivalent of NifENassociated "FeMoco", and the difference between the two cluster species reflects the impact of homocitrate on Mo incorporation (unpublished data). To investigate whether $\mathrm{V}$ and $\mathrm{Fe}$ can be heterologously incorporated into the NifEN-associated FeMoco precursor, four NifEN forms-NifEN"FeVco", NifEN"FeV", NifEN “FeFeco", and NifEN" ${ }^{\mathrm{FeFe}}$ ", respectively-were prepared using the same procedures as those used for the generation of NifEN"FeMoco" and NifEN"FeMo", except that Mo(VI) (supplied in the form of $\mathrm{MoO}_{4}{ }^{2-}$ ) in the incubation mixture was replaced by $\mathrm{V}(\mathrm{V})$ (supplied in the form of $\mathrm{VO}_{3}{ }^{-}$) and $\mathrm{Fe}(\mathrm{III})$ (supplied in the form of $\mathrm{FeCl}_{3}$ ), respectively. These $\mathrm{V}$ - and Fe-treated NifEN forms were subsequently compared with the Mo-bound forms of NifEN for the assessment of heterometal insertion into the NifEN-bound 
precursors (see "Materials and methods" for the preparation of the various NifEN forms in this work).

\section{EPR analyses}

The NifEN-associated precursor undergoes a significant transformation upon the attachment of Mo, as both NifEN "FeMoco" and NifEN "FeMo" display EPR features that are different from those of NifEN ${ }^{\text {Precursor }}$ (Fig. 1). The insertion of Mo introduces similar $S=3 / 2$ signals (which center at $g=3.96$ ) into the EPR spectra of NifEN"FeMoco" and NifEN"FeMo", both in the dithionite-reduced (Fig. 1a) and in the IDS-oxidized (Fig. 1b) states. Additionally, in the dithionite-reduced state, a $g=2.03$ feature appears in the spectra of both NifEN "FeMoco" and NifEN "FeMo" (Fig. 1a, red and blue traces). Concurrent with the appearance of these Mo-associated EPR features, the $S=1 / 2$ signals of dithionite-reduced NifEN "FeMoco" and NifEN "FeMo" decrease in magnitude by approximately $50 \%$ upon Mo insertion (Fig. 1a), whereas the $g=1.92$ feature (Fig. 1b, black trace) disappears completely in the spectra of IDS-oxidized NifEN"FeMoco" and NifEN"FeMo" (Fig. 1b). As the $g=1.92$ feature and approximately $50 \%$ of the $S=1 / 2$ signal have been previously assigned to the NifEN-associated precursor, ${ }^{1}$ the disappearance of these signals along with the appearance of the Mo-associated signals represent the conversion of the precursor to a Mo-containing cluster species [14]. Therefore, these parameters can be used to monitor the insertion of other heterometals into the NifEN-associated precursor.

Upon treatment with $\mathrm{V}$ or $\mathrm{Fe}$, the NifEN-associated precursor undergoes changes that are similar to yet distinct from those associated with the insertion of Mo. Like NifEN "FeMoco" and NifEN "FeMo", in the dithionite-reduced state, NifEN"FeVco", NifEN "FeV”, NifEN "FeFeco", and

\footnotetext{
${ }^{1}$ NifEN contains two types of clusters: an $\left[\mathrm{Fe}_{4} \mathrm{~S}_{4}\right]$-type cluster at the $\alpha \beta$-dimer interface and an FeMoco precursor (containing seven or eight $\mathrm{Fe}$ atoms) at the cofactor site in the $\alpha$-subunit [5, 6]. Previous EPR analyses revealed that the $S=1 / 2$ signal in the EPR spectrum of dithionite-reduced NifEN is a mixture of signals originating from both the $\left[\mathrm{Fe}_{4} \mathrm{~S}_{4}\right]$ cluster and the precursor, which behave differently upon variations of temperature and power [6]. On the basis of these power- and temperature-dependent EPR experiments, approximately half of the $S=1 / 2$ signal was assigned to the precursor, and the other half was assigned to the permanent $\left[\mathrm{Fe}_{4} \mathrm{~S}_{4}\right]$ cluster [6]. Upon Mo insertion, the portion of the $S=1 / 2$ signal that originates from the precursor (approximately 50\%) disappears, whereas the portion of the $S=1 / 2$ signal that originates from the $\left[\mathrm{Fe}_{4} \mathrm{~S}_{4}\right]$ cluster (approximately 50\%) remains [8]. The $g=1.92$ feature has been assigned to the precursor on the basis of the observation of this signal in the spectrum of the IDS-oxidized NifEN (which contains both the precursor and the $\left[\mathrm{Fe}_{4} \mathrm{~S}_{4}\right]$ cluster) but not in the spectrum of the IDSoxidized $\triangle$ nifB NifEN (which contains only the $\left[\mathrm{Fe}_{4} \mathrm{~S}_{4}\right]$ cluster as a result of nifB deletion) [6].
}

NifEN"FeFe" (Fig. 1a) all display $S=1 / 2$ signals of reduced intensity relative to that displayed by NifEN $^{\text {Precursor }}$ (Fig. 1a). However, in these cases, the levels of signal reduction are much lower than those in the cases of NifEN"FeMoco" and NifEN "FeMo". Similarly, the $g=1.92$ feature of the precursor is reduced in size in the spectra of IDS-oxidized NifEN "FeVco", NifEN"FeV", NifEN "FeFeco", and NifEN"FeFe" (Fig. 1b); however, in contrast to what is observed in the cases of NifEN "FeMoco" and NifEN "FeMo", this feature is far from being obliterated from the spectra of these NifEN forms. Perhaps the biggest difference between the Mo-bound and the V- or Fe-treated cluster species is the absence of an $S=3 / 2$ signal in the latter cases, although a new feature appears at $g=2.01$, which can be best visualized in the spectra of both dithionite-reduced and IDS-oxidized NifEN "FeVco" (Fig. 1). Together, these observations suggest that $\mathrm{V}$ and Fe can be incorporated into the NifEN-bound precursor. However, the lesser degree of decrease in the sizes of the precursor-associated signals upon $\mathrm{V}$ and $\mathrm{Fe}$ treatment, particularly in the absence of homocitrate, points to a lesser degree of metal incorporation into the V- and Fe-bound NifEN forms. Moreover, the absence of a distinctive $S=3 / 2$ signal from the spectra of $\mathrm{V}$ - and Fe-bound NifEN forms suggests that, compared with the Mo-bound clusters, these V- and Fe-containing clusters possess different electronic properties (which may originate from the different spectroscopic properties of $\mathrm{V}$ and $\mathrm{Fe}$ ) and/or they are present in different protein environments [which could indicate a different conformational rearrangement of NifEN (or the lack thereof) upon the insertion of $\mathrm{V}$ or $\mathrm{Fe}$ (see "Native PAGE" for further discussion)].

\section{Activity assays}

Recently, it was reported that NifEN ${ }^{\text {Precursor }}$ is capable of catalyzing the reduction of some substrates of $\mathrm{MoFe}$ protein [i.e., acetylene $\left(\mathrm{C}_{2} \mathrm{H}_{2}\right)$ and azide $\left.\left(\mathrm{HN}_{3}\right)\right]$, albeit at lower specific activities [15]. Compared with $\mathrm{NifEN}^{\text {Precursor }}$, both NifEN "FeMoco" and NifEN"FeMo" display nearly no $\mathrm{C}_{2} \mathrm{H}_{2}$ and $\mathrm{HN}_{3}$-reducing activities on their own, particularly in the case of NifEN"FeMoco" (Table 1). On the other hand, both NifEN "FeMoco" and NifEN "FeMo" can activate (or reconstitute) the FeMoco-deficient $\triangle$ nifB $\mathrm{MoFe}$ protein (Table 1), and the level of $\triangle$ nifB $\mathrm{MoFe}$ protein reconstitution by NifEN "FeMoco" is comparable to that by isolated FeMoco [14]. Interestingly, NifEN ${ }^{\text {Precursor }}$ shows its highest activities in $\mathrm{C}_{2} \mathrm{H}_{2}$ and $\mathrm{HN}_{3}$ reduction at $0.4 \mathrm{mM}$ dithionite, whereas these activities of $\mathrm{NifEN}^{\text {Precursor }}$ are practically eliminated at $20 \mathrm{mM}$ dithionite [15]. The optimal Mo incorporation into $\mathrm{NifEN}^{\text {Precursor }}$, on the other hand, occurs at $20 \mathrm{mM}$ dithionite, as NifEN "FeMoco" prepared at $20 \mathrm{mM}$ dithionite displays approximately threefold higher activity 
Fig. 1 EPR properties of various NifEN forms in (a) dithionite-reduced and (b) IDSoxidized states. Black $\mathrm{NifEN}^{\text {Precursor }}$, red

NifEN "FeMoco", blue

NifEN" "FeMo", brown

NifEN"FeVco", cyan NifEN"FeV", pink NifEN "FeFeco", green NifEN"FeFe". The dithionitereduced samples were measured at $6 \mathrm{~K}$, whereas the IDSoxidized samples were measured at $15 \mathrm{~K}$. The $S=3 / 2$ signals of NifEN “FeMoco" and NifEN"FeMo" are enlarged, and the $g$ values are indicated. The $g$ values of the features associated with the precursor $(g=2.07$, 1.91, and 1.84), the Mo-bound clusters $(g=4.45,3.96$, and 3.60), and the V- and Fe-bound clusters $(g=2.01)$ are labeled in green, black, and brown, respectively

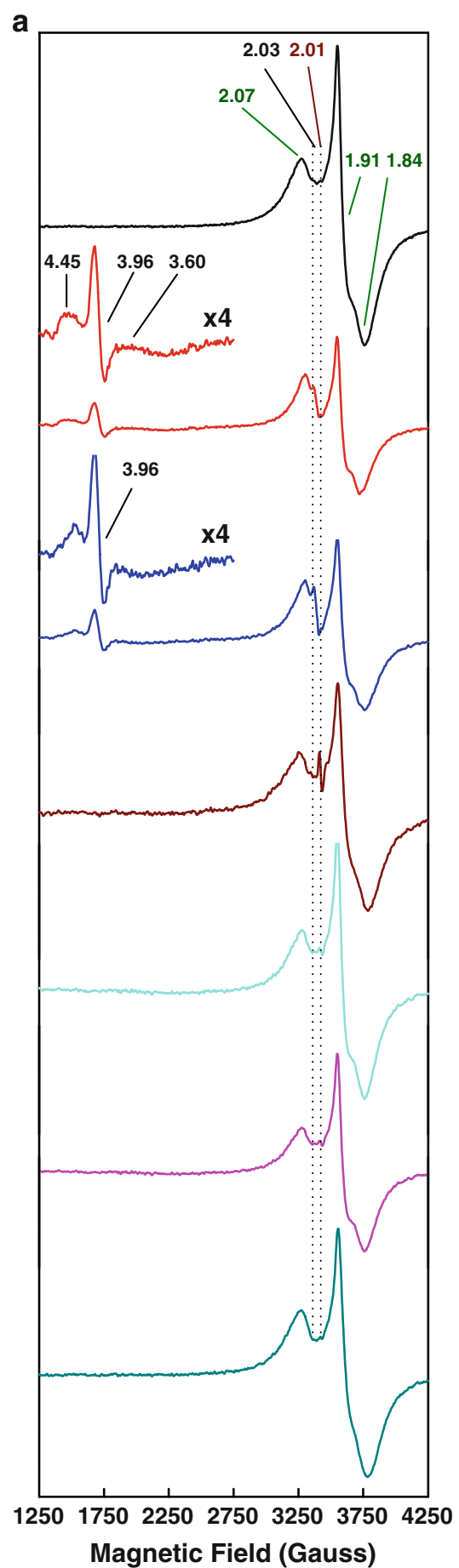

in reconstituting the $\triangle$ nifB $\mathrm{MoFe}$ protein than NifEN "FeMoco" prepared at $0.4 \mathrm{mM}$ [14]. Apparently, there is a redoxdependent "switch" between the catalytic and biosynthetic capacities of NifEN, as the calculated solution potentials of 0.4 and $20 \mathrm{mM}$ dithionite are approximately -490 and $-440 \mathrm{mV}$, respectively [16]. More importantly, the disappearance of the substrate-reducing activities of b

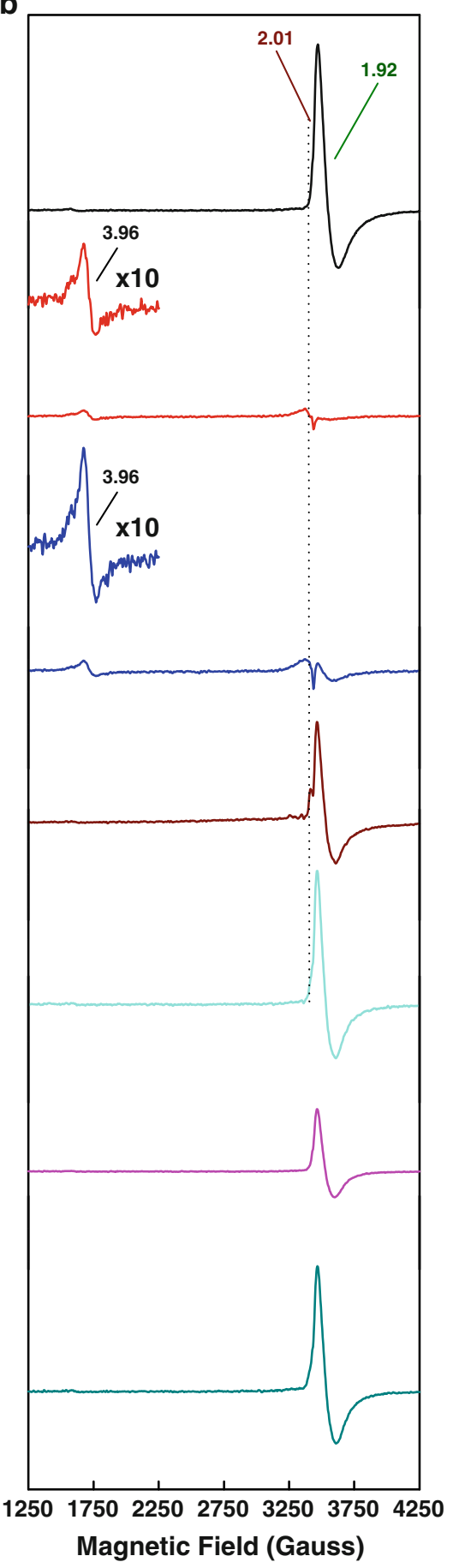

NifEN"FeMoco" and NifEN"FeMo" — which indicates the disappearance of the catalytically competent precursor upon insertion of metal-correlates with the disappearance of the precursor-specific features in their EPR spectra (Fig. 1). Thus, the decrease in the substrate-reducing activities of NifEN"FeMoco" and NifEN"FeMo", along with the increase in their capacities to reconstitute $\Delta$ nifB $\mathrm{MoFe}$ 
Table 1 The substrate-reducing and reconstitution activities of various NifEN forms

\begin{tabular}{|c|c|c|c|c|c|}
\hline \multirow[t]{2}{*}{ Assay type } & \multicolumn{5}{|l|}{ Activities } \\
\hline & $\begin{array}{l}\mathrm{C}_{2} \mathrm{H}_{4} \text { formation } \\
\text { under } \mathrm{C}_{2} \mathrm{H}_{2} / \mathrm{Ar}\end{array}$ & $\begin{array}{l}\mathrm{H}_{2} \text { formation } \\
\text { under } \mathrm{Ar}\end{array}$ & $\begin{array}{l}\mathrm{NH}_{3} \text { formation } \\
\text { under } \mathrm{N}_{2}\end{array}$ & $\begin{array}{l}\mathrm{H}_{2} \text { formation } \\
\text { under } \mathrm{N}_{2}\end{array}$ & $\begin{array}{l}\mathrm{NH}_{3} \text { formation } \\
\text { from } \mathrm{HN}_{3}\end{array}$ \\
\hline \multicolumn{6}{|c|}{ Substrate-reducing activities ${ }^{\mathrm{a}}$} \\
\hline NifEN $^{\text {Precursor }}$ & $52 \pm 7$ & 0 & 0 & 0 & $73 \pm 10$ \\
\hline NifEN"FeMoco” & $3 \pm 1(94)$ & 0 & 0 & 0 & $5 \pm 1(93)$ \\
\hline NifEN"FeMo” & $7 \pm 5(87)$ & 0 & 0 & 0 & $8 \pm 1(89)$ \\
\hline NifEN"FeVco” & $24 \pm 7(54)$ & 0 & 0 & 0 & $43 \pm 2(41)$ \\
\hline NifEN"FeV” & $34 \pm 2(35)$ & 0 & 0 & 0 & $55 \pm 5(25)$ \\
\hline NifEN“FeFeco” & $12 \pm 4(77)$ & 0 & 0 & 0 & $12 \pm 4(84)$ \\
\hline NifEN"FeFe” & $37 \pm 4(29)$ & 0 & 0 & 0 & $35 \pm 2(52)$ \\
\hline \multicolumn{6}{|c|}{ Reconstitution activities $^{\mathrm{b}}$} \\
\hline NifEN ${ }^{\text {Precursor }}$ & 0 & 0 & 0 & 0 & ND \\
\hline NifEN"FeMoco” & $1,065 \pm 88$ & $1,100 \pm 19$ & $334 \pm 40$ & $323 \pm 23$ & ND \\
\hline NifEN"FeMo” & $55 \pm 9$ & $62 \pm 5$ & $50 \pm 16$ & $64 \pm 7$ & ND \\
\hline NifEN"FeVco” & $12 \pm 1$ & $12 \pm 1$ & 0 & $7 \pm 2$ & ND \\
\hline NifEN"FeV” & $<1$ & 0 & 0 & $2 \pm 1$ & ND \\
\hline NifEN"FeFeco” & $15 \pm 1$ & $22 \pm 2$ & 0 & 0 & ND \\
\hline NifEN"FeFe” & $3 \pm 1$ & 0 & 0 & $<1$ & ND \\
\hline
\end{tabular}

Percentage decreases in the substrate-reducing activities of various NifEN forms relative to those of NifEN ${ }^{\text {Precursor }}$ are given in parentheses. The lower detection limits are $0.01,0.02,0.001$, and $0.02 \mathrm{nmol} / \mathrm{min} / \mathrm{mg}$ of protein for $\mathrm{C}_{2} \mathrm{H}_{4}$ formation under $\mathrm{C}_{2} \mathrm{H}_{2} / \mathrm{Ar}, \mathrm{H}_{2}$ formation under $\mathrm{Ar}, \mathrm{NH}_{3}$ formation under $\mathrm{N}_{2}$, and $\mathrm{H}_{2}$ formation under $\mathrm{N}_{2}$, respectively

$N D$ not determined

a Assays were performed in the presence of $0.4 \mathrm{mM}$ dithionite as described in "Materials and methods." The substrate-reducing activities of various NifEN forms were measured by replacing MoFe protein with NifEN in the nitrogenase activity assays. Data are expressed as nanomoles per minute per milligram of NifEN

b Assays were performed in the presence of $20 \mathrm{mM}$ dithionite as described in "Materials and methods." The reconstitution activities of various NifEN forms were measured by combining NifEN (the source of the cofactor) with the cofactor-deficient $\Delta$ nifB MoFe protein (the acceptor of the cofactor) in the nitrogenase reconstitution assays. NifEN ${ }^{\text {Precursor }}$ does not show any substrate-reducing activity under these conditions [15]. Therefore, all activities detected in these assays originate from the MoFe protein upon reconstitution by the NifEN forms that carry matured cofactors/clusters. Data are expressed as nanomoles per minute per milligram of $\Delta$ nifB MoFe protein

protein, can be used to analyze the extent to which $\mathrm{V}$ and Fe are heterologously inserted into the NifEN-associated precursor.

Like the Mo-treated NifEN (i.e., NifEN"FeMoco" and NifEN"FeMo"), V-treated NifEN (i.e., NifEN"FeVco" and NifEN"FeV") and Fe-treatred NifEN (i.e., NifEN"FeFeco" and NifEN "FeFe") exhibit decreased $\mathrm{C}_{2} \mathrm{H}_{2}$ and $\mathrm{HN}_{3}$ reducing activities relative to $\mathrm{NifEN}^{\text {Precursor }}$ (Table 1). However, the $\mathrm{V}$ - and Fe-treated NifEN forms show a lesser degree of decrease in activity than the Mo-treated NifEN forms, especially in the absence of homocitrate (Table 1). The $\mathrm{V}$ - and Fe-treated forms of NifEN can also activate $\Delta$ nifB MoFe protein (Table 1); yet, compared with the Mo-bound forms of NifEN, the levels of activation of $\triangle$ nifB MoFe protein by these NifEN forms are greatly diminished and, in particular, the capacities of the homocitratedeficient V- and Fe-bound NifEN (i.e., NifEN "FeV" and NifEN "FeFe") to activate the $\triangle$ nifB MoFe protein are nearly abolished (Table 1).
The changes in the catalytic activities and the spectroscopic features of NifEN upon heterometal insertion can be quantitatively expressed by setting the percentage decreases in the activities of substrate reduction (i.e., $\mathrm{C}_{2} \mathrm{H}_{2}$ and $\mathrm{HN}_{3}$ reduction) and those in the sizes of the $S=1 / 2$ signal (dithionite-reduced) and the $g=1.92$ feature (IDS-oxidized) of NifEN"FeMoco" (as compared with NifEN ${ }^{\text {Precursor }}$ ) to represent the complete conversion of the precursor, and calculating the percentage decreases in these three parameters of the other NifEN forms relative to those of NifEN"FeMoco" (Fig. 2). Clearly, there is a strong correlation between these three parameters, which align well with one another in each case (Fig. 2). Moreover, a tendency of increased metal incorporation in the presence of homocitrate can be observed in all cases (Fig. 2, NifEN "FeMoco" vs. NifEN"FeMo", NifEN"FeVco" vs. NifEN"FeV”, NifEN"FeFeco" vs. NifEN"FeFe"). Finally, the level of metal incorporation under these experimental conditions can be assigned in the order $\mathrm{Mo}>\mathrm{Fe}>\mathrm{V}$, as this is the order of the 


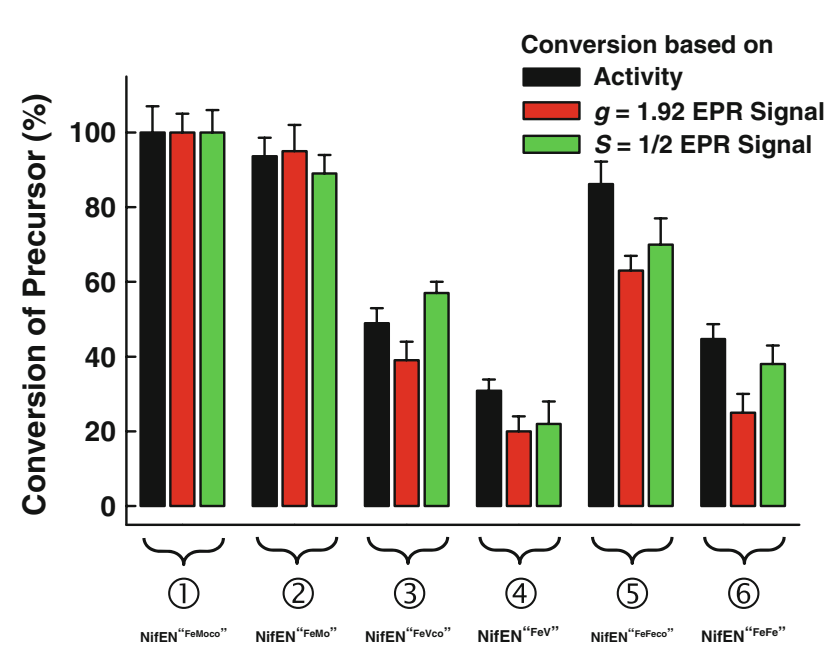

Fig. 2 Conversion of NifEN-associated precursor to various cofactors/clusters. Shown are the percentages of cluster conversion in NifEN"FeMoco" (1), NifEN"FeMo" (2), NifEN"FeVco" (3), NifEN"FeV" (4), NifEN"FeFeco" (5), and NifEN"FeFe" (6). The percentage of cluster conversion in NifEN"FeMoco" was set as $100 \%$ (1), where the actual percentage decreases in the substrate-reducing activity $(1$, black $)$, in the intensity of the $g=1.92$ EPR feature $(1$, red $)$, and in the intensity of the $S=1 / 2$ signal $(1$, green $)$ of NifEN "FeMoco" are 94, 100, and $50 \%$, respectively, relative to those of NifEN ${ }^{\text {Precursor }}$. The levels of cluster conversion in other NifEN forms were calculated on the basis of the percentage decreases in the substrate-reducing activity (2-6, black), in the intensity of the $g=1.92$ EPR feature $(2-6$, red $)$, and in the intensity of the $S=1 / 2$ signal (2-6, green) relative to those of NifEN"FeMoco" (1, set at $100 \%)$

percentage decreases in the three parameters of the Mo-treated (Fig. 2, NifEN "FeMoco" and NifEN "FeMo"), Fe-treated (Fig. 2, NifEN"FeFeco" and NifEN"FeFe"), and V-treated (Fig. 2, NifEN"FeVco" and NifEN"FeV") NifEN forms. $^{2}$

\section{Native PAGE}

The insertion of heterometal can be further monitored by complex formation between NifEN (the cofactor donor) and $\triangle$ nif $B$ MoFe protein (the cofactor acceptor) at an approximate molar ratio of $1: 1$ in the anaerobic native PAGE. When NifEN ${ }^{\text {Precursor }}$ is mixed with $\triangle$ nifB $\mathrm{MoFe}$ protein, two separate bands can be visualized in the native gel, suggesting that these two proteins cannot form a strong complex (Fig. 3, lane 1). NifEN "FeMoco" (Fig. 3, lane 2) or

\footnotetext{
2 The metal contents of the various NifEN forms have been analyzed by colorimetric methods and inductively coupled plasma mass spectrometry analyses. The degrees of precursor conversion in NifEN"FeMo", NifEN"FeVco", and NifEN"FeV" are 90, 60, and 42\%, respectively, by taking the Mo content in NifEN"FeMoco" as a result of complete cluster conversion and comparing the Mo or $\mathrm{V}$ content of NifEN"FeMo", NifEN"FeVco", and NifEN"FeV" with the Mo content of NifEN" "FeMoco" (data not shown). These numbers are consistent with the percentages of precursor conversion derived from the EPR and activity analyses (Fig. 2).
}

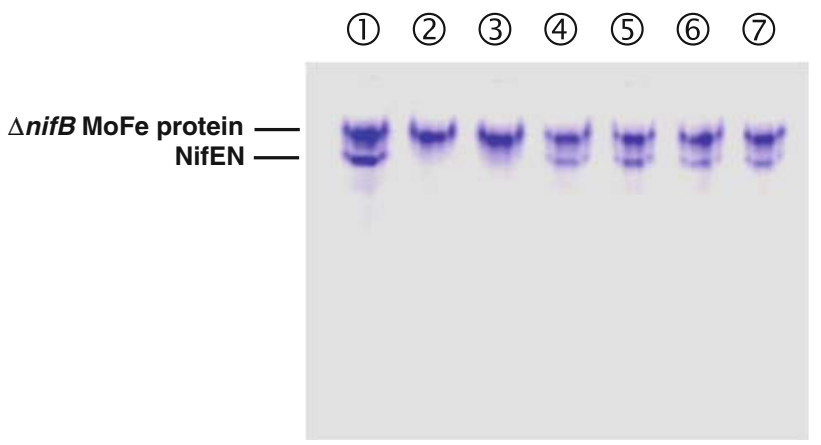

Fig. 3 Anaerobic native polyacrylamide gel electrophoresis of equimolar mixtures of $\triangle$ nifB $\mathrm{MoFe}$ protein and various NifEN forms. Lane $1 \Delta$ nifB MoFe protein plus NifEN ${ }^{\text {Precursor }}$, lane $2 \Delta$ if $B \mathrm{MoFe}$ protein plus NifEN"FeMoco", lane $3 \Delta$ nifB MoFe protein plus NifEN"FeMo", lane $4 \Delta$ nifB MoFe protein plus NifEN"FeVco", lane 5 $\triangle$ nifB MoFe protein plus NifEN “FeV", lane $6 \triangle$ nifB MoFe protein plus NifEN “FeFeco", and lane $7 \Delta$ nifB MoFe protein plus NifEN"FeFe"

NifEN"FeMo" (Fig. 3, lane 3), on the other hand, forms a tight band in the native gel upon incubation with $\Delta$ nifB $\mathrm{MoFe}$ protein, suggesting that both can form complexes with the $\triangle$ nifB $\mathrm{MoFe}$ protein. There is a certain level of complex formation between $\triangle$ nifB $\mathrm{MoFe}$ protein and NifEN"FeVco" (Fig. 3, lane 4), NifEN"FeV" (Fig. 3, lane 5), NifEN "FeFeco" (Fig. 3, lane 6), or NifEN"FeFe" (Fig. 3, lane 7 ), as the lower NifEN band is reduced in intensity in all cases. However, consistent with the much reduced levels of $\mathrm{V}$ and Fe incorporation (Fig. 2), the NifEN band is still clearly visible, which either represents the unconverted portion of NifEN (i.e., NifEN ${ }^{\text {Precursor }}$ ) that is unable to complex with the $\triangle$ nifB MoFe protein or suggests an "incorrect" conformational change of NifEN upon the heterologous incorporation of $\mathrm{V}$ or $\mathrm{Fe}$ that renders it incapable of complex formation with the $\triangle$ nifB MoFe protein (Fig. 3, lanes 4-7). The latter account would be consistent with our proposal that the missing $S=3 / 2$ signal in the cases of $\mathrm{V}$ - and Fe-treated NifEN forms may reflect the differences in the protein environments where the $\mathrm{V}-, \mathrm{Fe}-$, and Mo-containing clusters reside (see "EPR analyses"). Together, these results suggest a "productive" conformational rearrangement of NifEN upon the effective insertion of the "correct" heterometal into the precursor.

\section{Discussion}

Our observation that $\mathrm{V}$ and Fe can be incorporated into the NifEN-associated precursor suggests the ability of $\mathrm{Fe}$ protein to mobilize metals other than Mo. Indeed, it was reported earlier that $\mathrm{V}$ and $\mathrm{Mn}$ can bind to the Fe protein in the presence of nucleotide [17, 18]. Additionally, in the case of $\mathrm{V}$, it has been demonstrated that $\mathrm{V}(\mathrm{V})$ (supplied in the form of $\mathrm{VO}_{4}{ }^{3-}$ ) is reduced to $\mathrm{V}(\mathrm{IV})$ by the Fe protein 
before it can bind to the nucleotide binding site of the latter [17]. This finding is consistent with the outcome of our previous X-ray absorption spectroscopy/extended X-ray absorption fine structure analysis, which indicates a decrease in the effective oxidation state of Mo (as compared with the supplied form of $\mathrm{MoO}_{4}{ }^{2-}$ ) upon its binding to the Fe protein in an ATP-dependent process, as well as a further reduction of Mo when homocitrate is attached to it [9]. Thus, the Fe protein/ATP-mediated heterometal mobilization may involve the proper reduction of any given metal (in association with the homocitrate) by the Fe protein, which in turn governs the efficiency at which the metal is "loaded" onto the Fe protein. This argument is particularly valid in light of the redox-dependent nature of the metal incorporation into the NifEN-associated precursor (see "Results"). The poor efficiencies of $\mathrm{V}$ and $\mathrm{Fe}$ insertion under the optimal conditions for Mo insertion, therefore, can be explained by the "incorrect" redox potential that is achieved by the in vitro dithionite/Fe protein (encoded by nifH) system. Under the in vivo conditions, the "correct" redox potentials for $\mathrm{V}$ and $\mathrm{Fe}$ insertion are likely accomplished by the $v n f H$ - and anfHencoded Fe proteins, which differ from that attained by the nifH-encoded $\mathrm{Fe}$ protein. It has been reported that in Azotobacter chroococcum the vnfH-encoded Fe protein has a midpoint potential different from that of the nifH-encoded Fe protein in the MgADP-bound state [19]. Thus, it is possible that the selectivity of heterometals for the cofactor centers of the Mo-, V-, and Fe-dependent nitrogenases is determined by the different redox potentials of the $\mathrm{Fe}$ protein components of these nitrogenases.

Concomitant with the incorporation of Mo into the NifEN-associated precursor, NifEN apparently undergoes a conformational change that allows the subsequent delivery of FeMoco from NifEN to MoFe protein upon direct protein-protein interaction (see "Results"). As NifEN is highly homologous to the MoFe protein, such a conformational change of NifEN likely occurs during the Fe-protein-mediated metal insertion process, where $\mathrm{Fe}$ protein interacts with NifEN in a manner that is analogous to that of its interaction with the MoFe protein during catalysis. Thus, the "correct" interaction between the $\mathrm{Fe}$ protein and NifEN is crucial for the proper transfer of the matured cofactor from its assembly site in NifEN to its final binding site in MoFe protein. Given the existence of two scaffold proteins for the assembly of nitrogenase cofactors (i.e., NifEN and VnfEN), as well as the presence of three homologous yet distinct Fe proteins (i.e., nifH-, $v n f H$-, and anfH-encoded Fe proteins), it is possible that the interaction between a particular Fe protein and its designated scaffold protein during the process of metal insertion is unique to each of the three homologous nitrogenase systems. These differential scaffold protein-Fe protein interactions, along with the redox regulation of metal mobilization by Fe proteins, may provide the structuralchemical basis for the metal specificity of nitrogenase cofactor biosynthesis.

Acknowledgments This work was supported by National Institutes of Health grant GM 67626 (M.W.R.) and Herman Frasch Foundation grant 617-HF07 (M.W.R.).

Open Access This article is distributed under the terms of the Creative Commons Attribution Noncommercial License which permits any noncommercial use, distribution, and reproduction in any medium, provided the original author(s) and source are credited.

\section{References}

1. Eady RR (1996) Chem Rev 96:3013-3030

2. Rees DC, Tezcan FA, Haynes CA, Walton MY, Andrade S, Einsle O, Howard JB (2005) Philos Trans R Soc A 363:971-984

3. Burgess BK, Lowe DJ (1996) Chem Rev 96:2983-3012

4. Harvey I, Arber JM, Eady RR, Smith BE, Garner CD, Hasnain SS (1990) Biochem J 266:929-931

5. Dos Santos PC, Dean DR, Hu Y, Ribbe MW (2004) Chem Rev 104:1159-1173

6. Hu Y, Fay AW, Ribbe MW (2005) Proc Natl Acad Sci USA 102:3236-3241

7. Corbett MC, Hu Y, Fay AW, Ribbe MW, Hedman B, Hodgson KO (2006) Proc Natl Acad Sci USA 103:1238-1243

8. Hu Y, Corbett MC, Fay AW, Webber JA, Hodgson KO, Hedman B, Ribbe MW (2006) Proc Natl Acad Sci USA 103:17119-17124

9. Hu Y, Corbett MC, Fay AW, Webber JA, Hodgson KO, Hedman B, Ribbe MW (2006) Proc Natl Acad Sci USA 103:17125-17130

10. Burgess BK, Jacobs DB, Stiefel EI (1980) Biochim Biophys Acta 614:196-209

11. Ribbe MW, Hu Y, Guo M, Schmid B, Burgess BK (2002) J Biol Chem 277:23469-23476

12. Schmid B, Ribbe MW, Einsle O, Yoshida M, Thomas LM, Dean DR, Rees DC, Burgess BK (2002) Science 296:352-356

13. Ribbe MW, Burgess BK (2001) Proc Natl Acad Sci USA 98:5521-5525

14. Yoshizawa JM, Blank MA, Fay AW, Lee CC, Wiig JA, Hu Y, Hodgson KO, Hedman B, Ribbe MW (2009) J Am Chem Soc 131:9321-9325

15. Hu Y, Yoshizawa JM, Fay AW, Lee CC, Wiig JA, Ribbe MW (2009) Proc Natl Acad Sci USA 106:16962-16966

16. Mayhew SG (1978) Eur J Biochem 85:535-547

17. Fisher K, Lowe DJ, Petersen J (2006) Chem Commun 2807-2809

18. Petersen J, Gessner C, Fisher K, Mitchell DJ, Lowe DJ, Lubitz W (2005) Biochem J 391:527-539

19. Bergström J, Eady RR, Thorneley RNF (1988) Biochem J 251:165-169 